\title{
Sr-Nd-Pb-Hf-Mg isotopes tracing fossil ridge subduction: a case study in the easternmost Central Asian Orogenic Belt
}

FENG WANG ${ }^{1,2 *}$, KAI-CHEN XING ${ }^{1}$, WEN-LIANG XU ${ }^{1}$, FANG-ZHEN TENG ${ }^{2}$

${ }^{1}$ College of Earth Sciences, Jilin Univeristy, Changchun, Jilin 130061, China (*jlu_wangfeng@jlu.edu.cn)

${ }^{2}$ Isotope Laboratory, Department of Earth and Space Sciences, University of Washington, Seattle, WA 98105, USA

Igneous rocks related to abnormal high heat flow preserved in ancient convergent margins provide direct clues to identify fossil ridge-subduction. The Khanka Massif, as a witness of the final termination of the Paleo-Asian Ocean in Late Paleozoic, provides an ideal opportunity to trace the fossil ridge-subduction. Different types of Permian igneous rocks (282-255 Ma) were identified in composition from mafic to felsic. The mantle-derived mafic rocks are further subdivided into two groups. Group I are arc-featured rocks with normal mantle features in $\mathrm{Mg}$ isotopes. Permian subduction setting was therefore proposed within western margin of Khanka Massif, supported by the coeval arcfeatured granitoids and the detrital zircon cumulative proportion curves. Group II are tholeiitic and have more depleted $\mathrm{Sr}-\mathrm{Nd}-\mathrm{Pb}-\mathrm{Hf}$ isotopic compositions similar to MORB of Paleo-Asian Ocean. In addition, the decoupling between $\mathrm{Sr}-\mathrm{Nd}-\mathrm{Pb}-\mathrm{Hf}$ and $\mathrm{Mg}$ isotopes indicate the isotope exchange between MORB and magnesite. High heat condition is therefore required because of the decomposition reactions of magnesite. As to the crust-derived felsic rocks, they exhibit the prominent difference in Sr-Nd-Pb-Hf-Mg isotopes, implying synchronous melting of the continental and oceanic crusts, which are supported by the high zircon saturation temperatures $\left(855-935^{\circ} \mathrm{C}\right)$. Consequently, an 'abnormal high-heat condition' caused by ridge subduction and resultant slab window is the most likely model to reconcile the diversiform magmatism and tectonic evolution along the west margin of the Khanka Massif in the Permian. $\mathrm{Sr}-\mathrm{Nd}-\mathrm{Pb}-\mathrm{Hf}-\mathrm{Mg}$ isotopes are therefore verified as an integrated tracer to decipher the magmatic response to the ridge-subduction in ancient subduction zone.

This work was financially supported by the National Natural Science Foundation of China (Grants 91858211, 41722204) 